\title{
Behavior of genetic (co)variance components in populations simulated from non-additive genetic models of dominance and overdominance
}

\author{
Elizângela Emídio Cunha ${ }^{1}$, Ricardo Frederico Euclydes², Paulo Sávio Lopes ${ }^{2}$, Robledo de \\ Almeida Torres ${ }^{2}$, Paulo Luiz Souza Carneiro ${ }^{3}$
}

\footnotetext{
1 Departamento de Genética - CB - UFRN/Natal, RN.

2 Departamento de Zootecnia - CCA - UFVIViçosa, MG. Bolsista do CNPq.

${ }^{3}$ Departamento de Ciências Biológicas - CCB - UESB/Jequié, BA.
}

\begin{abstract}
The aim of this work was to investigate the short-term behavior of the genetic variability of quantitative traits simulated from models with additive and non-additive gene action in control and phenotypic selection populations. Both traits, one with low $\left(h^{2}=0.10\right)$ and the other with high $\left(h^{2}=0.60\right)$ heritability, were controlled by 600 biallelic loci. From a standard genome, it was obtained six genetic models which included the following: only the additive gene effects; complete and positive dominance for 25, 50, 75 and 100\% of the loci; and positive overdominance for 50\% of the loci. In the models with dominance deviation, the additive allelic effects were also included for $100 \%$ of the loci. Genetic variability was quantified from generation to generation using the genetic variance components. In the absence of selection, genotypic and additive genetic variances were higher. In the models with non-additive gene action, a small magnitude covariance component raised between the additive and dominance genetic effects whose correlation tended to be positive on the control population and negative under selection. Dominance variance increased as the number of loci with dominance deviation or the value of the deviation increased, implying on the increase in genotypic and additive genetic variances among the successive models.
\end{abstract}

Key Words: closed population, computer simulation, dominance deviation, genetic variability, intralocus interaction

\section{Comportamento dos componentes de (co)variância genética em populações simuladas a partir de modelos genéticos não-aditivos de dominância e sobredominância}

\begin{abstract}
RESUMO - Objetivou-se estudar a variabilidade genética a curto prazo de características quantitativas simuladas a partir de modelos com ação gênica aditiva e não-aditiva em populações controle e de seleção fenotípica. As duas características, uma de baixa $\left(h^{2}=0,10\right)$ e outra de alta $\left(h^{2}=0,60\right)$ herdabilidade, foram controladas por 600 locos bialélicos. A partir de um genomapadrão, foram obtidos seis modelos genéticos que incluíram: apenas efeitos aditivos dos genes; dominância completa e positiva para 25, 50, 75 e 100\% dos locos; e sobredominância positiva para 50\% dos locos. Nos modelos com desvio da dominância também foram incluídos os efeitos aditivos dos alelos para 100\% dos locos. A variabilidade genética foi quantificada de geração a geração por meio de componentes de variância genética. Na ausência de seleção, as variâncias genotípica e genética aditiva mantiveram-se mais elevadas. Nos modelos com ação gênica não-aditiva, surgiu um componente de covariância entre os efeitos genéticos aditivos e de dominância de pequena magnitude e cuja correlação tendeu a ser positiva na população controle e negativa sob seleção. A variância de dominância aumentou com o acréscimo no número de locos com desvio da dominância ou no valor do desvio, o que implicou aumento das variâncias genotípica e genética aditiva entre os sucessivos modelos.
\end{abstract}

Palavras-chave: desvio da dominância, interação intraloco, população fechada, simulação em computador, variabilidade genética

\section{Introduction}

Genotypic variance is subdivided into additive and non-additive genetic variances. The latter is decomposed in the dominance genetic variance (caused by allele interaction in the same locus) and epistatic variance (resulting from interactions of alleles from different loci). In animal breeding, genetic response to selection is based on the accurate estimation of variance components.

In most genetic evaluations, only additive genetic variance is used, based on the following arguments: 1 ) only the alleles are passed down from one generation to the next and the genotype is recreated in each generation; 2) the correlation between the genotypic value and the presence 
of genes that increase the expression of the character, that is, favorable genes, is higher under the additive genetic model; 3) there are some computational difficulties related to statistical modeling with non-additive genetic effects; and 4) the presence and importance of these effects for the phenotypic variation of economically valuable traits are not clear.

The most important non-additive genetic effects are those of dominance (Gengler et al., 1998). Thus, like additive genetic variance, dominance variance causes the covariance among certain types of relatives (Cockerham, 1954). In this context, De Boer \& van Arendonk (1992) and Du et al. (1999) emphasized the need to know the covariance between the additive and dominance effects in an inbred population, in order to calculate the genetic covariance between two relatives with arbitrary levels of inbreeding.

The growing interest in the effects of dominance is a result of the evolution of reproductive biotechnologies such as artificial insemination, multiple ovulation, in vitro fertilization, embryo transfers and cloning, which potentially increase the number of related animals in the population, especially full sibs, thereby increasing dominance relationships, within and between generations, in herds in which these techniques are used (VanRaden et al., 1992).

In this study, the non-additive genetic effects of dominance and overdominance were emphasized using gene action models with a considerable number of loci. The aim of this work was to evaluate the short-term behavior of the genetic variability of quantitative traits, determined by different genetic models, in populations of random mating and phenotypic selection.

\section{Material and Methods}

The data used in this study originated in gene-level simulations using the GENESYS program (Euclydes, 1996; Euclydes et al., 1996), written in FORTRAN.

The configured standard genome had a total length of 4,000 cM and contained 600 biallelic quantitative loci, randomly distributed in 36 pairs of autosomal chromosomes of random sizes, varying by around $15 \%$.
Sex chromosomes were not simulated. With this standard genome, six genetic models were simulated: one with only the additive genetic effects; four with complete positive dominance for $25,50,75$ and $100 \%$ of the loci and one with positive overdominance for $50 \%$ of the loci (Table 1), from which the evaluated populations were structured.

These models differed by the types of gene action allowed to the alleles in their loci: completely additive, that is, with dominance deviation of zero $(\mathrm{d}=0)$ in all the loci; and heterotic, with non-additive dominance or overdominance gene interaction, that is, with positive directional dominance deviation ( $d>0$ ) between the alleles of a same locus. The additive effect was simulated under normal distribution and it was present in $100 \%$ of the loci in all the models, even in the interaction models, whereas the dominance deviation was simulated with uniform distribution for a variable percentage of loci. The initial frequency of the favorable allele was simulated with mean of 0.50 and it followed the normal distribution.

The $d / a$ relation, in which $a$ is the genotypic value of the favorable homozygote and $d$ is that of the heterozygote, measures what is called the degree of dominance of a gene. Thus, in genetic models with dominance effects, it was the complete type and it aimed at the favorable allele $(d / a=+1)$, that is, the genotypic value of the heterozygote individual was identical to that of the favorable homozygote. In the model with overdominance $(\mathrm{d} / \mathrm{a}=+2)$, the heterozygous genotype had a value $100 \%$ higher than that of the favorable homozygote.

To calculate the genetic effects, it was considered that the genotypic value $(G)$ relative to one locus consisted of the additive genetic value (A) of its alleles and the value of dominance deviation (D) between them, if present, so that $G=A+D$. The individual genotypic value $\left(G_{I}\right)$ was obtained by applying the sum of all the loci controlling the expression of the trait of the individual. The phenotypic value of the individual $\left(\mathrm{F}_{\mathrm{I}}\right)$ consisted of the components of the genotypic value $\left(\mathrm{G}_{\mathrm{I}}\right)$ and the temporary environmental effect $\left(\mathrm{E}_{\mathrm{I}}\right)$, as follows: $F_{I}=G_{I}+E_{I}$. Under the additive genetic model, $G_{I}$ was the additive value $A_{I}$ itself.

Table 1 - Genetic models as a function of type of gene action

\begin{tabular}{lccc}
\hline Genetic model & $\begin{array}{c}\text { Type of } \\
\text { genetic action }\end{array}$ & $\begin{array}{c}\text { Mean degree of } \\
\text { dominance }(\mathrm{d} / \mathrm{a})\end{array}$ & $\begin{array}{c}\text { Loci affected by } \\
\text { dominance deviation }\end{array}$ \\
\hline AD - Additive & additive & 0 & 0 \\
D25 - Dominance for $25 \%$ of the loci & dominance & +1 & 150 \\
D50 - Dominance for $50 \%$ of the loci & dominance & +1 & 300 \\
D75 - Dominance for $75 \%$ of the loci & dominance & +1 & 450 \\
D100 - Dominance for $100 \%$ of the loci & dominance & +1 & 600 \\
OD - Overdominance for $50 \%$ of the loci & overdominance & +2 & 300 \\
\hline
\end{tabular}


At each generation, the additive (VA) and dominance (VD) variances were obtained using the following expressions: $V A=\sigma_{A}^{2}=\sum_{i=1}^{n} 2 p_{i} q_{i} \alpha_{i}^{2}$ and $V D=\sigma_{D}^{2}=\sum_{i=1}^{n} 4 p_{i}^{2} q_{i}^{2} d_{i}^{2}$, in which, considering $n$ loci, $\alpha_{i}=a_{i}+d_{i}\left(q_{i}-p_{i}\right)=$ mean effect of gene substitution in locus $i$; $p_{i}$ and $q_{i}=$ gene frequencies in the population of favorable and unfavorable alleles for locus $i$, respectively; $a_{i}=$ additive genetic value of locus $i$; and $d_{i}=$ dominance deviation of locus $i$.

In the population as a whole, genotypic variance (VG) by generation was obtained by $\mathrm{VG}=\mathrm{VA}+\mathrm{VD}+2 \mathrm{Cov}$ $(A, D)$, in which VA and VD are as previously defined; and $\operatorname{Cov}(A, D)$ is the sum for $n$ loci of the covariance between the additive and dominance genetic effects for a certain locus in two different individuals, considering the relationship between them. This covariance may be generalized as Cov $=r V A+u V D$, where $r$ is the fraction of the additive genetic variance and $u$ that of the dominance variance as a function of the pedigree considered (Falconer \& Mackay, 1996). The association between the additive and dominance effects by generation was determined using the correlation coefficient (r) and applying the t-test at significance levels of 1 and $5 \%$.

Two quantitative traits per genetic model were considered, one with low $\left(h^{2}=0.10\right)$ and the other with high $\left(\mathrm{h}^{2}=0.60\right)$ heritability, both influenced by all the genes of the standard genome and not correlated. Initial additive genetic variance was 0.40 and 0.15 for low and high heritability, respectively, which resulted in two distinct base populations with the same genomic architecture under each model, however.

For each simulated structure (genetic model - trait), the obtained base population had 1,000 individuals, equally divided between males and females and it was predominantly heterozygotous in the loci. The individuals of this population were randomly generated, including the formation of gametes that gave rise to them, the zygotogenesis phase and the definition of sexes, which characterized the nonexistence of relationship between them, given the absence of Mendelian segregations.

Ten males and 100 females were randomly chosen from the base population and then mated, generating five offspring per mating, for a total of 500 individuals. The new population formed was called the initial population, since the onset of relationship ties was observed among the animals.

The population under selection, obtained by reproduction of the initial population, had the following composition by generation and structure: 25 males and 100 females chosen for reproduction; five progenies per couple; real population size of 500; effective population size $\left(\mathrm{N}_{\mathrm{e}}\right)$ of 80 ; and 100 families of full sibs. The effective size was calculated through the formula $N_{e}=\frac{4 N_{m} N_{f}}{N_{m}+N_{f}}$, proposed by Wright (1931), cited by Falconer (1987), in which $\mathrm{N}_{\mathrm{m}}$ = the number of males and $\mathrm{N}_{\mathrm{f}}$ = the number of females effectively mated.

Two selection methods were used: random mating (control population) and phenotypic selection, for which parents were mated at random; and 10 consecutive and discrete generations advanced with 30 repetitions per generation to reduce genetic drift (Carneiro et al., 2008). The selection aimed at an increase in the mean phenotypic values of the traits.

A total of 24 populations, corresponding to six gene action models, two selection methods and two traits, were evaluated; and genotypic variance, additive and dominance genetic variances, as well as additive and dominance genetic covariance, were quantified in each one, generation after generation.

\section{Results and Discussion}

In the additive genetic model, considering low heritability $\left(h^{2}=0.10\right)$, the additive genetic variance of the selected population was less than that of the control population, except in the fourth generation, decreasing over time as a consequence of the selective process itself (Figure 1). However, narrow-sense heritability was similar in the two populations in the evaluated period.

For high heritability, it was observed the same tendency with respect to additive genetic variance, but there was a marked difference between populations in terms of narrow-sense heritability, which decreased over time under selection. In the first generation, additive genetic variance and narrow-sense heritability coincided in the two selection methods, whereas under low heritability this only occurred for narrow-sense heritability.

In the genetic model with complete positive dominance for $25 \%$ of the loci (Figure 2), the control population and the population under selection showed greater differences in relation to genotypic variance, which was higher in the former. Compared to the model with only additive genetic effects, additive genetic variance was similar in the two populations, with a slight decline in the selected population between the fifth and seventh generations and after the eighth.

The inclusion of dominance deviation in the genetic models resulted in dominance variance and in the emergence 

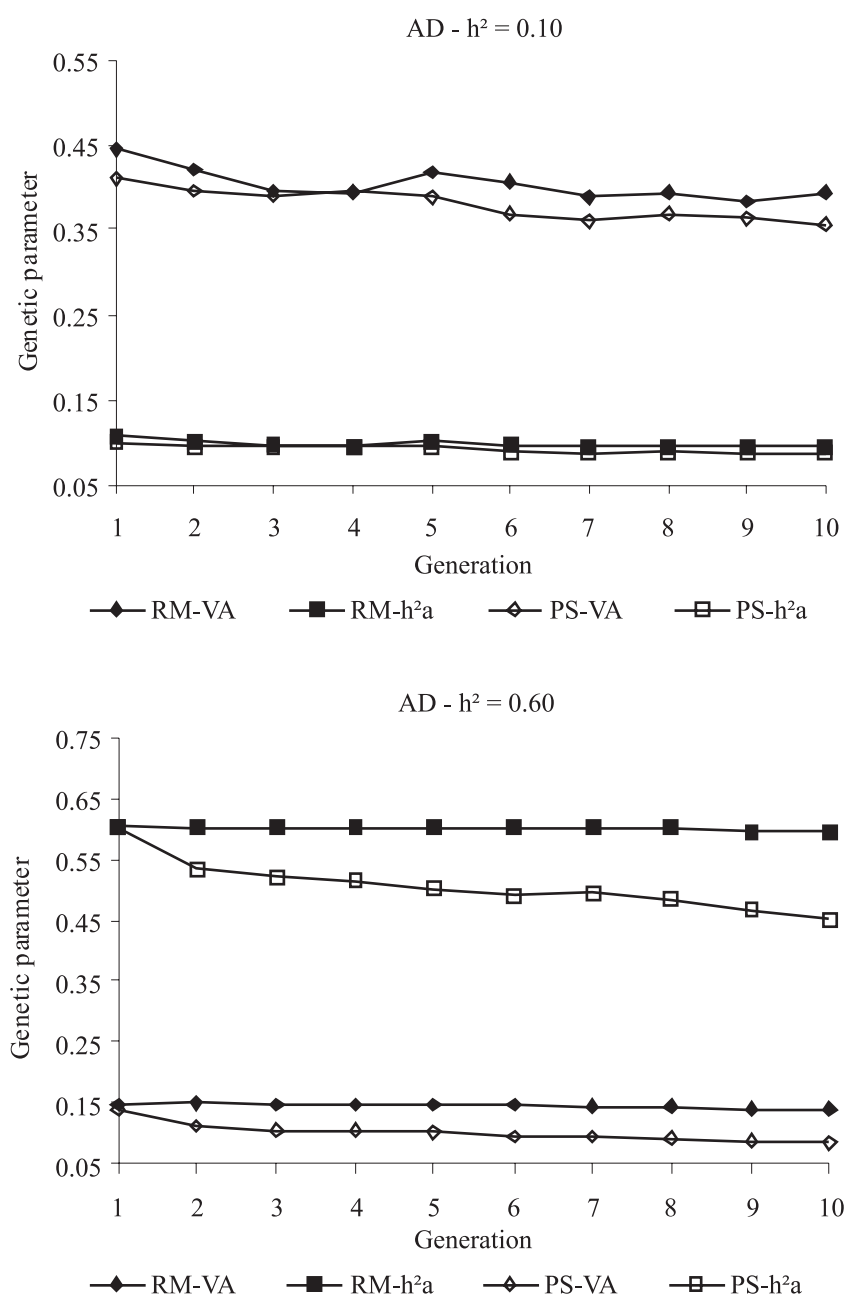

Figure 1 - Mean evolution of additive genetic variance (VA) and narrow-sense heritability $\left(\mathrm{h}^{2} \mathrm{a}\right)$ under random mating (RM) and phenotypic selection (PS) for the additive genetic model (AD), in each trait.

of covariance between the additive and dominance genetic effects, confirming the results obtained by Cunha et al. (2009a). Dominance variance in the models was practically the same in the populations; however, this covariance was of low magnitude and tended to increase across the generations under selection, with results between 0.1 and $8.6 \%$, which were always positive in the control population and predominantly negative in the selected population. The latter can be checked by observing the sign of the correlation coefficient between the additive and dominance effects by generation (Table 2). In the model with complete positive dominance for $25 \%$ of the loci, these effects were correlated $(\mathrm{P}<0.01)$ in both populations.

Under the dominance model for $50 \%$ of the loci, the greatest difference between the control population and the population under phenotypic selection occurred for genotypic variance. In this model, genotypic and additive genetic variances were greater in the control population. Additive genetic variance was more similar in the two populations than in the model with only additive genetic effects, whereas the dominance and genotypic variances increased compared to the dominance model for $25 \%$ of the loci. Furthermore, there was a slight increase in the magnitude of covariance between the additive and dominance effects that were correlated $(\mathrm{P}<0.01)$.

In the dominance model for $75 \%$ of the loci, the two populations also differed more in terms of genotypic variance, which remained higher in the control population. Additive genetic variance was higher under selection until the second generation, when it became similar in both populations, as it occurred with dominance variance. Compared to that observed in dominance models for 25 and $50 \%$ of the loci, there was an increase in dominance and genotypic variances as well as in the magnitude of covariance between the additive and dominance effects, especially in the selected population. Both under selection and in its absence, the correlation between these effects was significant $(\mathrm{P}<0.01)$ in the assessed period.

For the genome with dominance deviation in $100 \%$ of the loci, the variance components exhibited similar behavior to that described in models with deviation in 25, 50 and $75 \%$ of the loci when the assessed populations were compared, except additive genetic variance, which was higher under selection in most of the generations. Compared to these models, there was an increase in dominance variance and in magnitude of covariance between the additive and dominance effects, especially in the selected population, in which the additive and dominance effects showed a significant negative correlation $(\mathrm{P}<0.01)$, except in the first generation $(\mathrm{P}>0.05)$. In the absence of selection, these effects were positive and significantly correlated $(\mathrm{P}<0.01)$.

Additive genetic variance was similar among the random mating populations of the different models with complete dominance across the generations. However, in selected populations, as the percentage of loci with dominance deviation increased, there was a tendency to an increase in additive genetic variance, as reported by Cunha et al. (2009a), even though the additive and dominance effects were negatively correlated. This was most evident in the models that contained over $50 \%$ of the loci with dominance deviation and in the first generations. Another fact in the selected populations is that the covariance between the additive and dominance effects tended to increase in magnitude with advancing generations. This tendency was not observed in the control populations.

In the overdominance genetic model, the greatest difference between populations also occurred in relation to 

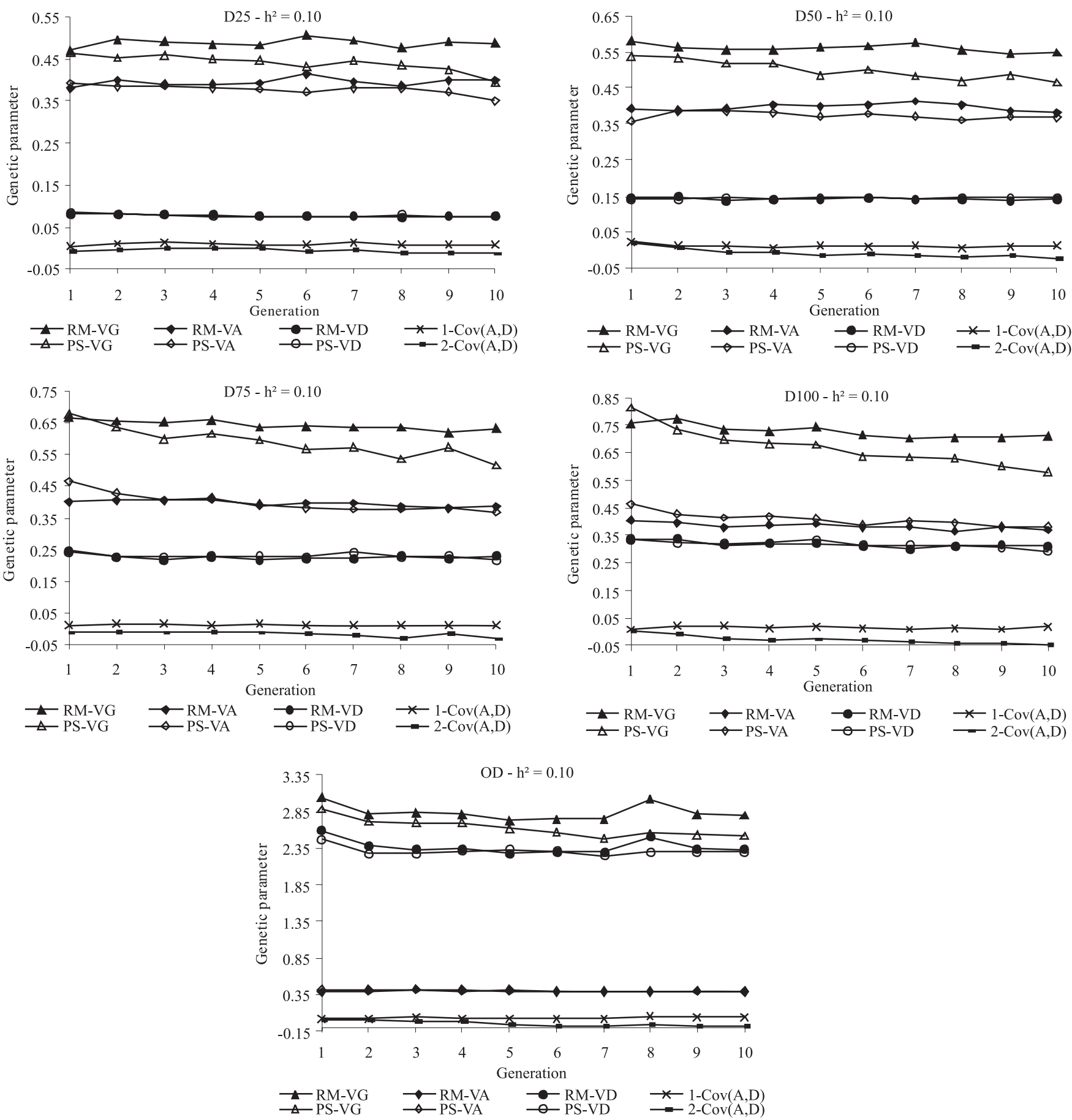

Figure 2 - Mean evolution of genotypic (VG), additive genetic (VA) and dominance (VD) variances and of covariance between the additive and dominance genetic effects $(\operatorname{Cov}(A, D))$ in the control $(R M ; 1)$ and phenotypic selection (PS; 2$)$ populations under the complete dominance genetic models D25, D50, D75 and D100 and in the overdominance genetic model OD in low heritability.

genotypic variance, which was especially higher than in the models with dominance and equally higher in the control population. Additive genetic variance was similar in the two populations and close to that of the other genetic models, generally remaining around the value initially attributed in the genome simulation. In this model, additive genetic variance decreased less across the generations. Since the heterozygous value was as twice as that of the dominant homozygote, with the selection of the heterozygote the probability of a given allele becoming fixed at a locus falls by $50 \%$, because it contains a single copy of each alternative allele per locus. In contrast to the models with complete dominance, a greater difference under overdominance was observed between the assessed populations in terms 
Table 2 - Correlation coefficient between the additive and dominance effects per generation in the two populations using the genetic model in low heritability

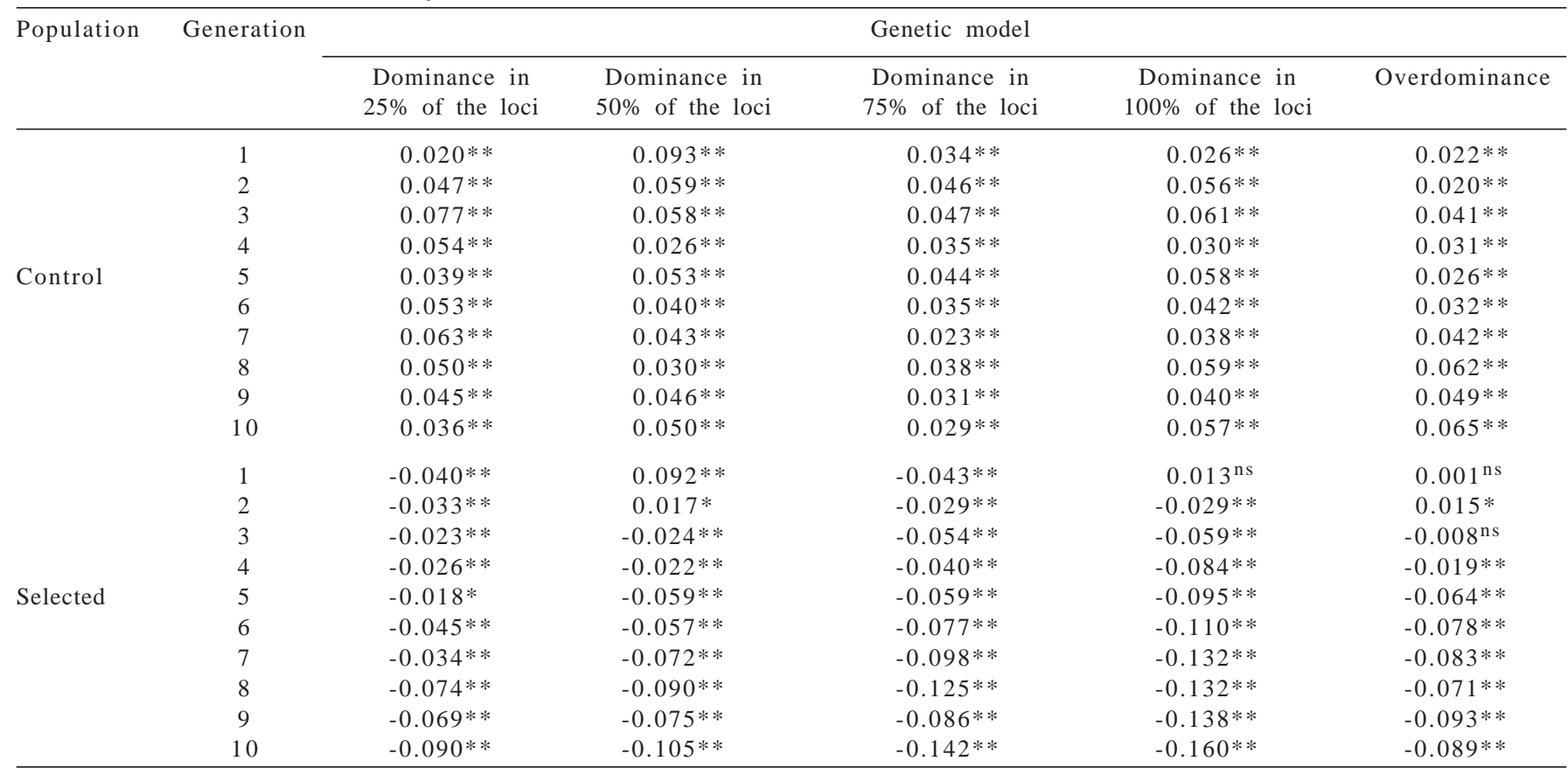

** and * significant correlations at 1 and $5 \%$ probability levels, respectively; and ns: non-significant.

of dominance variance, which was slightly higher in the control population. Additionally, it significantly increased according to the increase in dominance deviation value and also because, once selection in favor of the heterozygote occurs, gene frequencies tend to remain intermediate, thereby maximizing dominance variance. In the overdominance model under selection, the covariance and correlation between the additive and dominance genetic effects were both negative, except in generations 1 and 2 , and significant $(\mathrm{P}<0.01)$ after the third generation and in increasing magnitude. In the absence of selection, all the correlations were positive and significant $(\mathrm{P}<0.01)$.

Considering $h^{2}=0.60$ (Figure 3 ) in the model with dominance deviation in $25 \%$ of the loci, the greatest discrepancies between the assessed populations were in genotypic and additive genetic variances, which were higher in the control population and had the greatest decrease over time, under selection. Dominance variance was practically the same in the two populations, and nearly constant during the assessment period. As it was seen for $h^{2}=0.10$, a covariance component was established between the additive and dominance effects, whose magnitude ranged from 0 to $3.4 \%$ in the different models. This covariance behaved differently in the two populations, that is, it was always negative in each generation and of higher magnitude in the selected population, in addition to increasing among the generations. On the other hand, it was predominantly positive, not following any particular pattern in the random mating population. In the model with deviation in $25 \%$ of the loci, the correlation between the additive and dominance genetic effects was significant $(\mathrm{P}<0.01)$ in all the generations of the selected population (Table 3 ), whereas in the absence of selection, it was not significant $(\mathrm{P}>0.05)$ in most of the generations.

In the genetic models with dominance deviations in 50 , 75 and $100 \%$ of the loci, the genotypic, the additive genetic and the dominance variances showed similar behavior to that described in the model with deviation in $25 \%$ of the loci in the two populations. Covariance between the additive and dominance effects in the successive models also resulted in a predominantly positive correlation, sometimes significant $(\mathrm{P}<0.01$ or $\mathrm{P}<0.05)$, sometimes not significant $(P>0.05)$ in the generations of the control population. In the selected population, this covariance resulted in a negative correlation of increasing and significant magnitude $(\mathrm{P}<0.01)$ in most of the generations. Under high heritability, the (co)variance components of the overdominance model exhibited similar behavior to that reported for the same model in low heritability. However, the correlation between the additive and dominance effects was mostly nonsignificant $(\mathrm{P}>0.05)$ in the control population.

Additive genetic variance was close to its initial simulated value (0.15) in the different models, mainly 

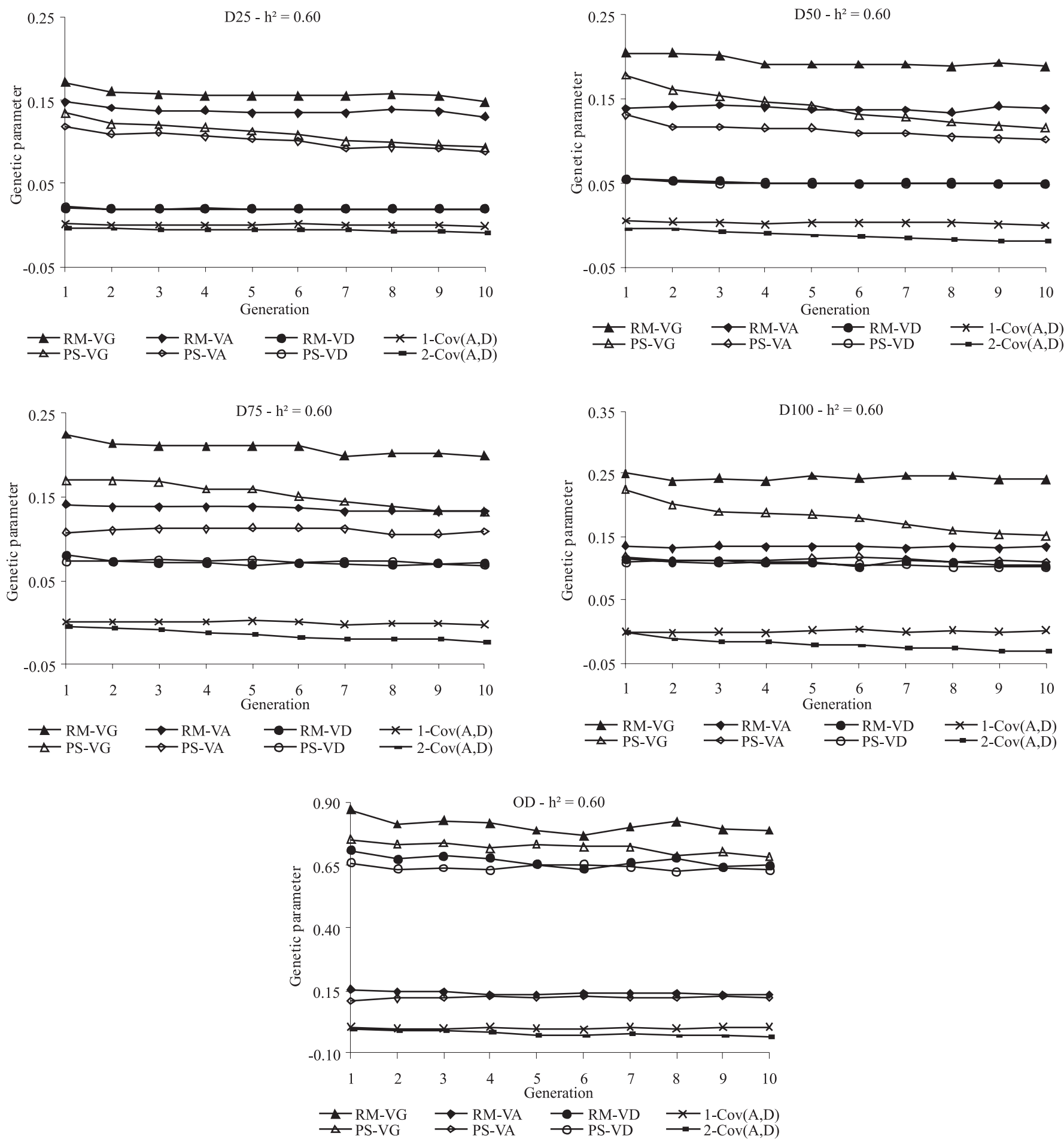

Figure 3 - Mean evolution of genotypic (VG), additive genetic (VA) and dominance (VD) variances and of covariance between the additive and dominance genetic effects $(\operatorname{Cov}(A, D))$ in the control $(R M ; 1)$ and phenotypic selection (PS; 2) populations under the complete dominance genetic models D25, D50, D75 and D100 and in the overdominance genetic model OD in high heritability.

under random mating, whereas genotypic variance gradually increased between them, but less intensely than for $\mathrm{h}^{2}=0.10$, which also occurred for the covariance between the additive and dominance effects, especially in the selected population.
In the non-additive models, the change in genotypic variance among the generations was caused by the change in additive and dominance genetic variances resulting from altered gene frequencies, which are more marked under selection, and considering the covariance between the 
Table 3 - Correlation coefficient between the additive and dominance effects by generation in the two populations using the genetic model in high heritability

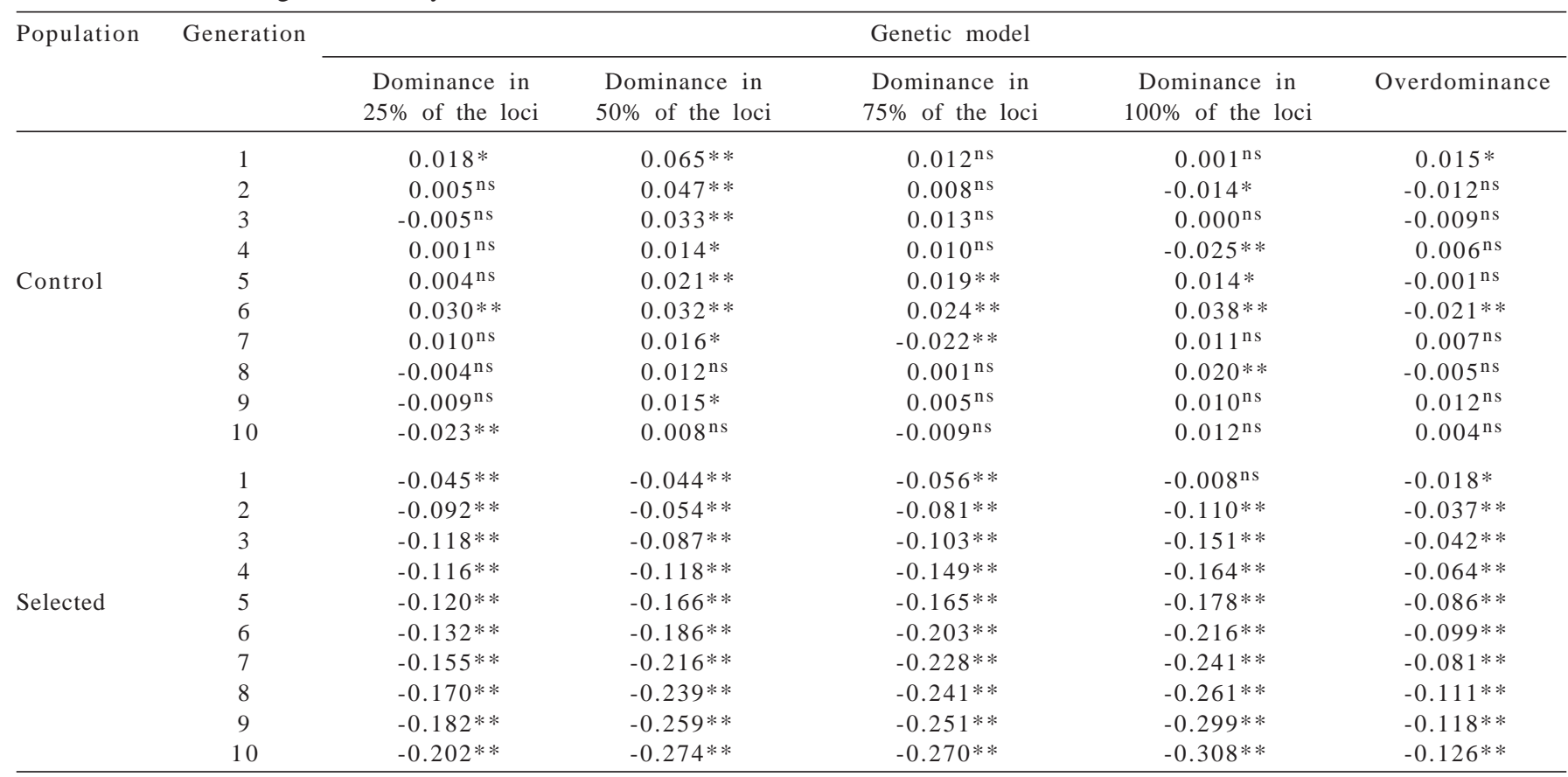

** and * significant correlations at 1 and $5 \%$ probability levels, respectively; and ns: non-significant.

additive and dominance effects. However, in the successive models, genotypic variance increased mainly by the increase in dominance variance because of the increase in the number of loci with dominance deviation or in the value of this deviation. Thus, the increase in dominance variance, more pronounced under low heritability, directly resulted in a higher genotypic variance, as well as indirectly in a slight increase in additive genetic variance, since dominance deviations are incorporated into the latter calculation (Cunha et al., 2009b).

The behaviors described in this study corroborate those obtained by Fuerst et al. (1997) in simulations involving 15 distinct genetic models, which included different combinations of additive, dominance and epistatic genetic variances. According to these authors, the non-additive variance contributes to the additive variance and thus, to the response to selection, if gene frequencies deviate from 0.50 , a fact that normally occurs under selection. Misztal et al. (1997) evaluated linear type traits in American Holstein cattle and found higher estimates of additive and dominance genetic variances, generally associated.

In animal selection, the increase in additive genetic variance caused by dominance deviation may result in overestimation of narrow-sense heritability and, consequently, in the genetic response for polygenic traits of economic interest controlled by dominant genes. Despite the fact that only the additive genetic effects are transmitted between generations, greater genetic progress could be achieved at the generation level by proper mating planning within the herd, which would allow for better exploitation of the entire available additive genetic variance.

In turn, the existence of kinship in populations is the main reason for the emergence in dominance models of a term relative to the covariance between the additive and dominance genetic effects for a particular locus in different individuals of the same generation. According to Lush (1964), when individuals of a same family are related through both of their parents, some correlation exists between their dominance deviations. In this study, the populations were structured in families of full sibs, at each generation.

Fuerst et al. (1997) found negative covariances between locus pairs, considering models that included additive, positive directional dominance and epistatic effects simultaneously. However, they reported higher negative magnitude values for this covariance under high heritability, which coincidentally was also 0.60 , whereas in this study the same tendency was observed under low heritability (0.10) and selection.

Irrespective of the trait, it was found that the correlation between the additive and dominance effects was weak and tended to be positive in the random mating populations and negative in the selected populations, in which it was statistically significant in most of the generations. Under 
selection, it is more likely that related individuals are coselected across the generations, increasing the chance of common ancestry and thus, of dominance relationships.

VanRaden et al. (1992) analyzed milk and fat production data, by means of different models using REML approximation, and found dominance variance estimates positively correlated with those of additive variance in the complete model, that is, which also included additive $\mathrm{X}$ additive genetic variance, but negatively correlated in models that omitted this epistatic variance.

\section{Conclusions}

The increase in dominance variance in non-additive genetic models reflects the increased number of loci with dominance deviation or increased deviation value, regardless of trait heritability. This causes an increase in genotypic variance and, to a lesser extent, in additive genetic variance. An association can be observed between the additive and non-additive genetic effects, which are weakly correlated in the random mating and phenotypic selection populations. This correlation is predominantly negative and significant under selection. The effects of dominance and overdominance may be relevant for predicting accurately the genetic response to the selection of traits potentially influenced by these effects, given that they affect the estimation of variance components.

\section{References}

CARNEIRO, P.L.S.; MALHADO, C.H.M.; AFFONSO, P.R.A.M. et al. Comparação de metodologias de seleção sob oscilação genética. Arquivo Brasileiro de Medicina Veterinária e Zootecnia, v.60, n.4, p.932-942, 2008.

COCKERHAM, C.C. An extension of the concept of partitioning hereditary variance for analysis of covariances among relatives when epistasis is present. Genetics, v.39, p.859-882, 1954.
CUNHA, E.E.; EUCLYDES, R.F.; TORRES, R.A. et al. Razões entre componentes da variabilidade de características quantitativas simuladas com efeitos genéticos de dominância e sobredominância. Revista Brasileira de Zootecnia, v.38, n.10, p.1893-1900, 2009a.

CUNHA, E.E.; EUCLYDES, R.F.; TORRES, R.A. et al. Impactos de se ignorarem os efeitos genéticos não-aditivos de dominância na avaliação genética animal. Revista Brasileira de Zootecnia, v.38, n.12, p.2354-2361, 2009b.

De BOER, I.J.M.; van ARENDONK, J.A.M. Prediction of additive and dominance effects in selected or unselected populations with inbreeding. Theoretical and Applied Genetics, v.84, p.451-459, 1992

DU, F.-X.; HOESCHELE, I.; GAGE-LAHTI, K.M. Estimation of additive and dominance variance components in finite polygenic models and complex pedigrees. Genetical Research, v.74, p.179-187, 1999.

EUCLYDES, R.F. Uso do sistema para simulação Genesys na avaliação de métodos de seleção clássicos e associados a marcadores moleculares. 1996. 149f. Tese (Doutorado em Genética e Melhoramento) - Universidade Federal de Viçosa, Viçosa, MG.

EUCLYDES, R.F.; MUIR, W.M.; SILVA, M.A. O sistema para simulação GENESYS. In: SIMPÓSIO DA SOCIEDADE BRASILEIRA DE MELHORAMENTO ANIMAL, 1., 1996, Ribeirão Preto. Anais... Ribeirão Preto: Sociedade Brasileira de Melhoramento Animal, 1996. p.87-98.

FALCONER, D.S. Introdução à genética quantitativa. Tradução de SILVA, M.A. e SILVA, J.C. Viçosa, MG: Imprensa Universitária, 1987. 279p.

FALCONER, D.S.; MACKAY, T.F.C. Introduction to quantitative genetics. 4.ed. Essex: Longman, 1996. 464p.

FUERST, C.; JAMES, J.W.; SÖLKNER, J. et al. Impact of dominance and epistasis on the genetic make-up of simulated populations under selection: a model development. Journal of Animal Breeding and Genetics, v.114, p.163-175, 1997.

GENGLER, N.; MISZTAL, I.; BERTRAND, J.K. et al. Estimation of the variance for postweaning gain in the $U$. S. Limousin population. Journal of Animal Science, v.76, p.2515-2520, 1998.

LUSH, J.L. Melhoramento genético dos animais domésticos. Centro de Publicações Técnicas da Aliança - USAID, 1964. 507p.

MISZTAL, I.; LAWLOR, T.J.; GENGLER, N. Relationships among estimates of inbreeding depression, dominance and additive variance for linear traits in Holsteins. Genetics, Selection and Evolution, v.29, p.319-326, 1997.

VanRADEN, P.M.; LAWLOR, T.J.; HOESCHELE, I. Use of reproductive technology to estimate variances and predict effects of gene interactions. Journal of Dairy Science, v.75, p.2892-2901, 1992. 